https://doi.org/10.15407/scine17.06.003

KALINICHENKO, O. V. (https://orcid.org/0000-0003-2688-859X), and LESYUK, V. S. (https://orcid.org/0000-0002-8370-6513)

Poltava State Agrarian University, 1/3, Skovorody St., Poltava, 36003, Ukraine, +380 53250 0273, pdaa@pdaa.edu.ua

\title{
ASSESSMENT OF THE FINANCIAL SECURITY LEVEL OF UKRAINE
}

Introduction. In the context of the development of globalization processes and the integration of the national economy into the global financial space, the issue of forming the financial security of Ukraine becomes increasingly important. It affects and links together all sectors of the national economy, business entities, society, politics, finance, etc.

Problem Statement. At the present stage of Ukraine's economic development, one of the primary task of government policy is to ensure the financial security of the state, after all, its ensuring aims at overcoming the economic crisis and improving the well-being of Ukrainian citizens.

Purpose. The assessment of the financial, monetary, and banking systems of Ukraine as well as the development of practically significant proposals are necessary for ensuring the financial security of Ukraine.

Materials and Methods. The analytical material is the data of the National Bank of Ukraine, which have been studied by economic and mathematical methods, statistical and indicative analysis.

Results. It has been determined that the state budget imbalance is the main destabilizing factor of the crisis in public finance. The dynamics of the number of banks in Ukraine have been studied: despite a decrease in the number of banks with foreign capital, their share in recent years has increased significantly, which hinders the effective development of the banking system of Ukraine. A significant underestimation of the domestic currency and large-scale devaluations in the previous years created unfavorable conditions for Ukrainian exporters, which resulted in a foreign trade balance deficit, an outflow of foreign currency and, accordingly, a decrease in the foreign exchange reserves.

Conclusions. The financial security strategy should determine the prospects for ensuring the stability of the financial, monetary, and banking systems and the development of the national economy. The implementation of financial, currency, credit measures, the adoption of amendments to the legislative framework, and the development of a financial security strategy for Ukraine become increasingly important, given the problems that exacerbate the financial security of Ukraine.

Keywords: financial security, monetary system, banking system, budget, external debt, banks, and national economy.

In the context of the development of globalization processes and the integration of the national economy into the global financial space, the issue of ensuring the financial security of Ukraine becomes increasingly important. It affects and links together all sectors

Citation: Kalinichenko O. V., and Lesyuk V. S. Assessment of the Financial Security Level of Ukraine. Sci. innov. 2021. V. 17, no. 6. P. 3-12. https://doi.org/10.15407/scine17.06.003 
of the national economy, business entities, society, politics, finance, etc. One of the most important factors in the national security, including its stability, integrity, and sustainable development, is to ensure financial security. At the present stage of Ukraine's economic development, one of the primary tasks of government policy is to ensure the financial security of the state, which determines the relevance of this topic. After all, ensuring financial security aims at overcoming the economic crisis and improving the well-being of Ukrainian citizens, and as a result, achieving the economic development of the state.

Various aspects of ensuring financial security have been highlighted by many researchers, including Boy N. [1], Vasylieva T. [2], Vasylchyshyn O.B. [3], De Goede M. [4], Ivanova O.B. [5], Kalantai A.M. [6], Nechiporuk L. V. [7], Radionov Yu.D. [8], Reznik O. [9], Smokvina A.A. [10], and Tarangul L.L. [11]. However, despite a significant number of publications, financial security has not been fundamentally justified, and the totality of indicators characterizing its state has not been fully studied. Considering Ukraine's current financial state, the topic outlined in the study becomes increasingly relevant and requires new proposals to overcome the growing economic crisis effectively.

The purpose of the research is to assess the financial, monetary, and banking systems of Ukraine, as well as to develop practically significant proposals for ensuring the financial security of Ukraine.

Financial security plays an important role in ensuring the national security of any state. Financial security is a factor for the effective development and competitiveness of the national economy at the international level. Ensuring financial security is the ultimate result of overcoming the current economic crisis.

Today, there is no single, well-established definition of the concept of "financial security". The existing formulations reflect only certain aspects of financial security and cannot pretend to have its unambiguous and exclusive interpretation. From the standpoint of a versatile approach, fi- nancial security is the protection of financial interests at all levels of financial relations; a certain level of independence, stability, and sustainability of the country's financial system in the context of the impact on it of external and internal destabilizing factors that threaten financial security; the ability of the financial system of the state to ensure the effective functioning of the national economic system and sustainable economic growth [12, 523-524].

The stability of the financial system is determined by budget deficit, price stability, stability of the national currency, the protection of the interests of bank depositors, the development of the stock market, the amount of international reserves, the development of the monetary market, the state of external debt, the balance of export-import transactions, the investment climate, the development of the market capitalization and the like.

Ensuring financial security at all government levels is an important task for many states, including Ukraine. It is impossible to solve the economic problems facing the state, region, and enterprise without providing them with financial security. This task becomes especially priority in the context of instability and financial crisis $[10,30]$.

At the present stage, the main national interests of Ukraine in the financial sphere include: ensuring financial stabilization, overcoming the payment crisis; reducing spending and budget deficits; implementing the tax system reform, strengthening its stimulating influence on the development of production; countering the shadow economy and decisively fighting corruption; eliminating arrears of social benefits; strengthening the national currency and ensuring its convertibility; reducing inflation and keeping it at 5\% annually.

An important instrument of state regulation of socio-economic processes is the State Budget of Ukraine. The imbalance in the state budget is the main destabilizing factor in the crisis of public finance. So, the state budget deficit amounted to UAH 47.85 billion (1.6\% of GDP), in 2017 ; UAH 59.25 billion (1.7\% to GDP), in 2018; and UAH 78.05 billion (2\% to GDP), in 2019. 


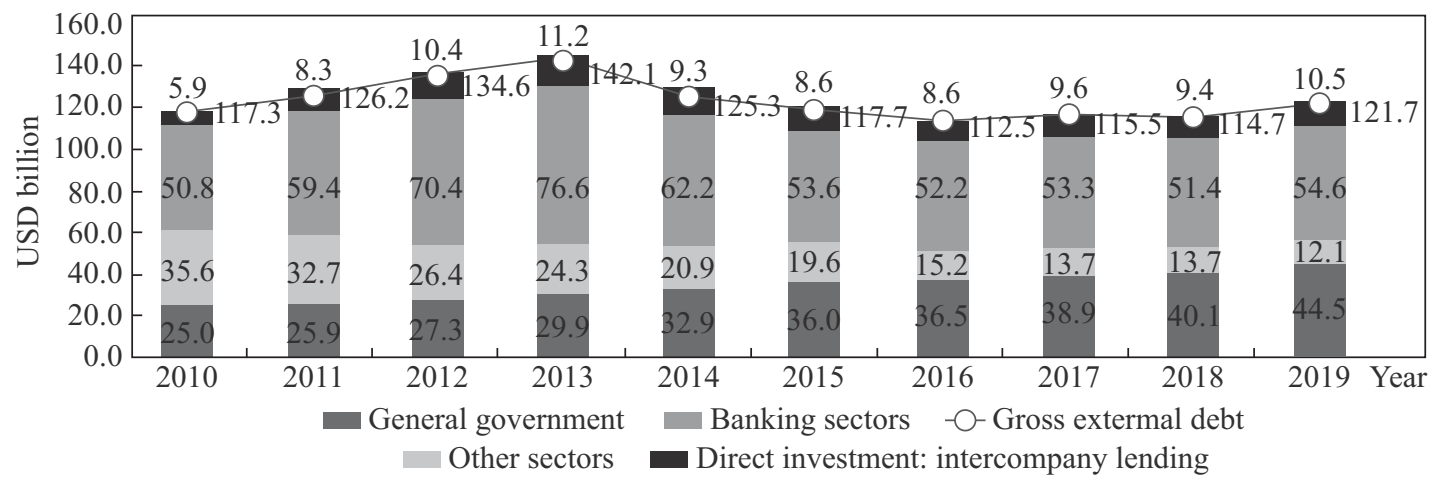

Fig. 1. Dynamics of Ukraine's external debt, 2010-2019, USD billion Source: estimated by the authors based on data [13].

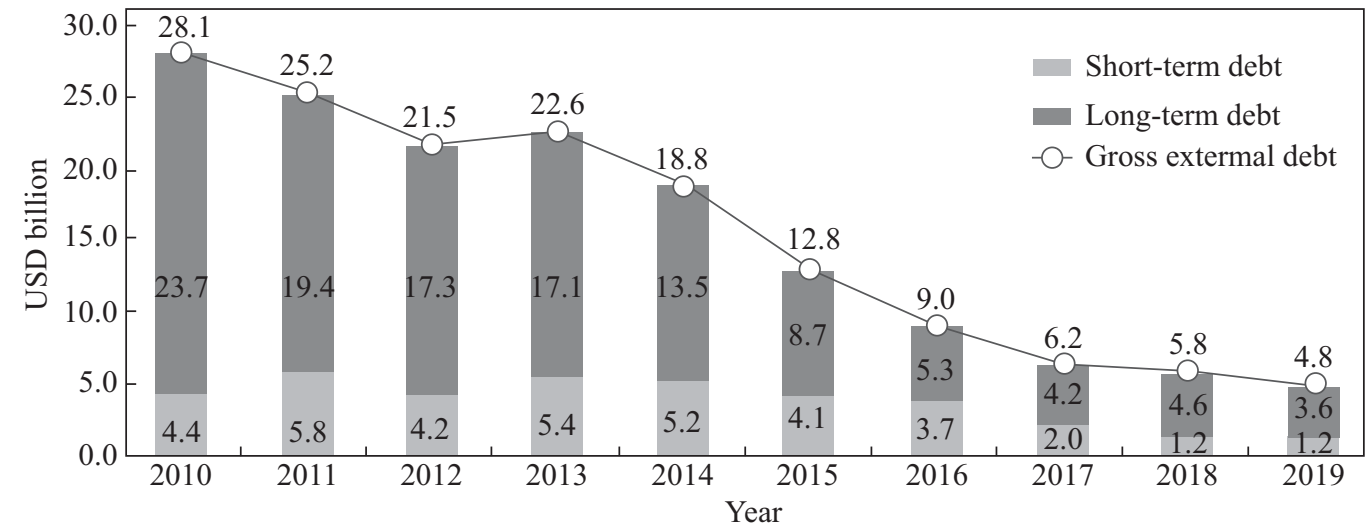

Fig. 2. Dynamics of the external debt of the banking sector of Ukraine, 2010-2019, USD billion Source: estimated by the authors based on data [13].

As of 2019, the external debt of the banking sector amounted to $9.9 \%$ of the total gross external debt of Ukraine (Fig. 1).

The main factor in an increase in the external debt in the past years was the deformation of the monetary market associated with a high cost of capital in the domestic market, the volatility of its market conditions, and limited long-term resources, which, in turn, reflect a low confidence in the banking system and incomplete transformation of national savings into domestic investment. In the conditions of the national economy, the attraction of external financing produces an insignificant effect on the dynamics of investments in fixed assets as main indicator of investment processes. This result indicates the need to eliminate deformations in the monetary market in order to ensure the investment and stimulating effect [14,33].

Over the past seven years, the banking sector debt has decreased 4.6 times and reached USD 4.8 billion (3.9\% of gross external debt), in 2019 , against USD 2.26 billion (15.9\%), in 2013 (Fig. 2).

One of the priority measures in terms of ensuring an adequate level of financial security in Ukraine should be the development of a monetary policy strategy and a strategy for the development of the banking system, which would determine the main goals of the National Bank of Ukraine and the development goals of the banking system, as well as measures, mechanisms and tools for managing the banking business. The main objectives of the monetary policy strategy should be the following: achieving exchange rate and price stabi- 


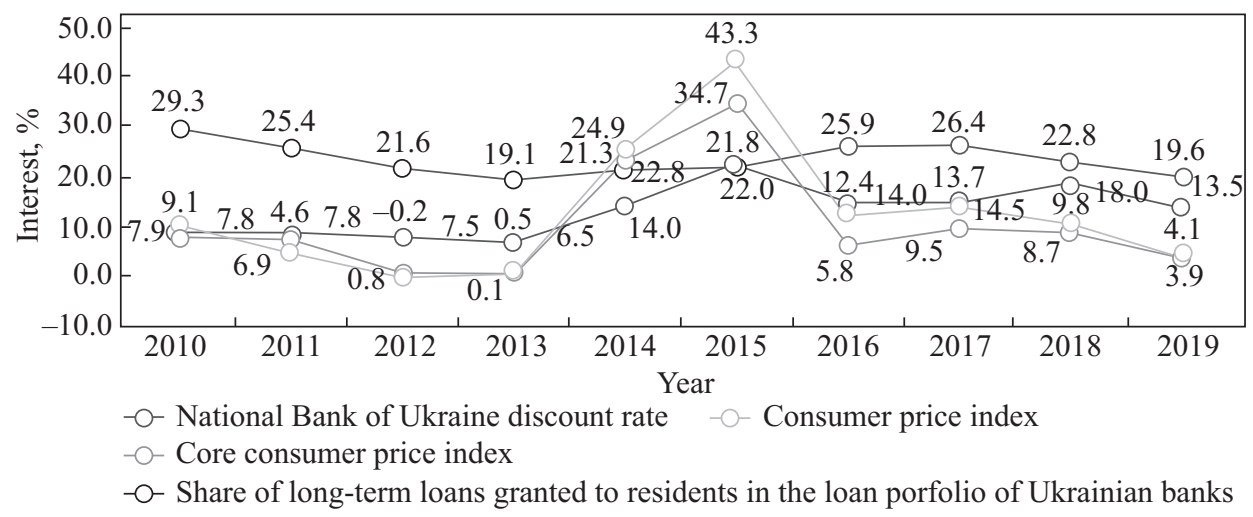

Fig. 3. Dynamics of the discount rate of the National Bank of Ukraine, the consumer price index, the core consumer price index, and the share of long-term loans granted to residents in the loan portfolio of Ukrainian banks, 2010-2019, \%

Source: estimated by the authors based on data [13].

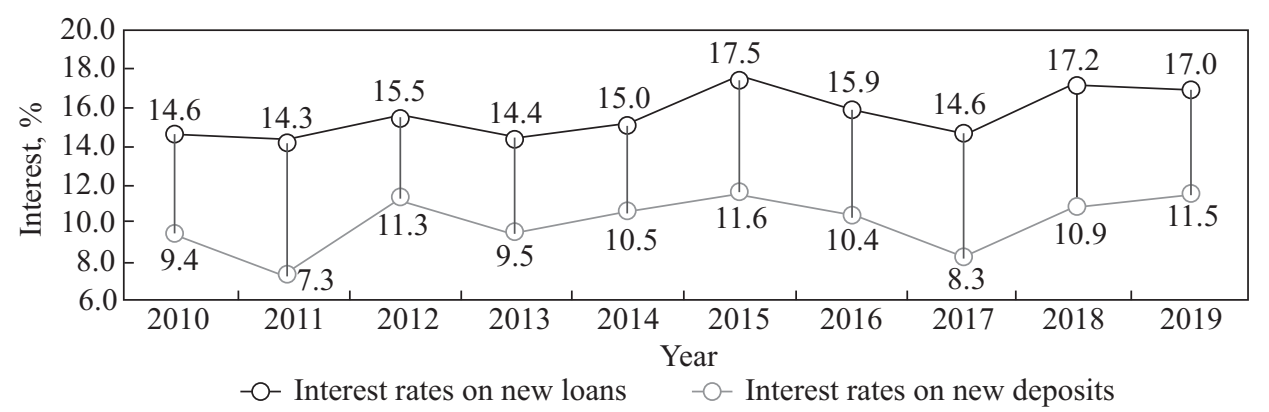

Fig. 4. Dynamics of interest rates on new loans and deposits, 2010-2019, \%

Source: estimated by the authors based on data [13].

lity through the use of instruments of monetary policy and exchange rate policy; refusal to finance the state budget through the redemption of bonds of the domestic government loan; a unified approach to the refinancing policy of commercial banks; restrictions on the use of foreign currency in credit transactions of banks, and in cash transactions of business entities and the population; restrictions on cash circulation in the state. Concerning the goals of the banking system development strategy, it is worth highlighting the following: creation and development of specialized development banks; establishing a quota for the presence of foreign capital in the banking system, in particular the banking capital of the aggressor country, supporting systemically important banks, developing lending to the real sector of the economy $[3,223]$.
The last three years have seen a steady downward trend in long-term lending. Its reduction is facilitated by the consistently high discount rate of the National Bank of Ukraine, the inflation rate and a decrease in the resource base of banks, because the higher the inflation rate in the country, the lower the share of loans in the loan portfolio of banks (Fig. 3).

Large-scale financial injections into the national economy are the main method of overcoming the crisis in many developed countries. One of the options is a plan to increase government funding by the emission of money. However, the emission of money should be directed to the domestic production of goods and services, in particular: electric power, chemical, petrochemical and fuel industries, mechanical engineering (aviation and automotive industries, railway, agricultural engi- 


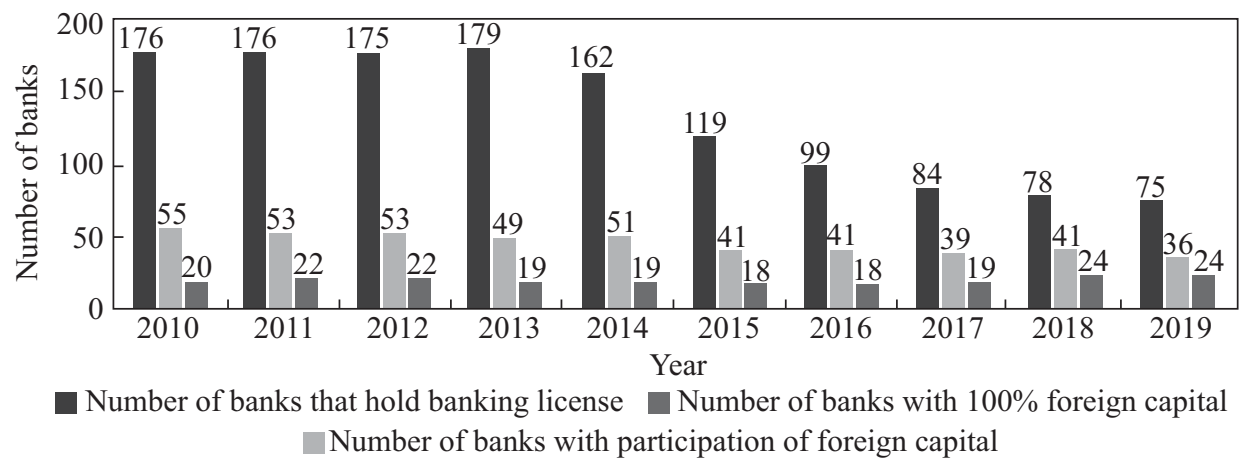

Fig. 5. Dynamics of the number of banks in Ukraine, 2010-2019

Source: estimated by the authors based on data [13].

neering, and shipbuilding), metallurgy, light and food industries.

Also, Ukraine has a significant gap between interest rates on new loans and deposits nominated in both national and foreign currencies. In developed countries, the excess of the credit rate over the deposit rate, as a rule, ranges from 2 to $3 \%$, while in Ukraine, in 2019, it is within 5.5\% (Fig. 4).

So, credit services are still expensive for clients, and deposit offers are not profitable enough. The instability of many banks in Ukraine requires the development of measures for state protection of banks and their clients from increased risk. However, one should take into account the whole range of problems associated with the development of the national economy of Ukraine.

The economic crisis in Ukraine has affected the plans of many foreign banks to carry out financial takeovers in Ukraine. Thus, despite a decrease in the number of banks with foreign capital, their share has increased significantly in recent years, which hinders the effective development of the banking system and increases threats to the financial security of Ukraine (Fig. 5).

As of 2019, in the banking sector of Ukraine, the number of banks with a banking license was 75 . Of these, 36 banks with foreign capital, including 24 banks with $100 \%$ foreign capital.

The banking system is the result of the action of both objective and subjective factors of influence on the formation, implementation, and development of the financial security of the state.
Low incomes of Ukrainian citizens have a negative impact on banking activities, and the unsatisfactory financial condition of borrowers requires the creation of significant reserves in banking institutions, which, in the absence of stable sources of resources, makes it difficult to form the resource base and the number of commercial banks. The dynamics of the number of banks shows that the growth of the resource potential of banks is in direct proportion to the level of public confidence in banking institutions. Financial policy, like national economic policy as a whole, depends on the existing legal field and the financial security of the state $[15,130]$.

Ensuring an adequate level of financial security of Ukraine's banking system requires the adoption of a set of measures to improve legislation, banking supervision, strategic planning, and anti-crisis management. The adoption of laws on foreign exchange regulation and lending, the introduction of riskoriented supervision of banks, stress testing, the creation of asset management companies and a bridge bank raise the level of financial security of the banking system of Ukraine, as well as, obviously, reduce internal and external threats. However, the improvement of these areas of banking management cannot be effective without a corresponding improvement in the state's general economic policy, as well as without the establishment of a mutually agreed monetary and fiscal policy $[3,225]$.

It is important to ensure that national money fulfills the functions of accumulation. It is in the 


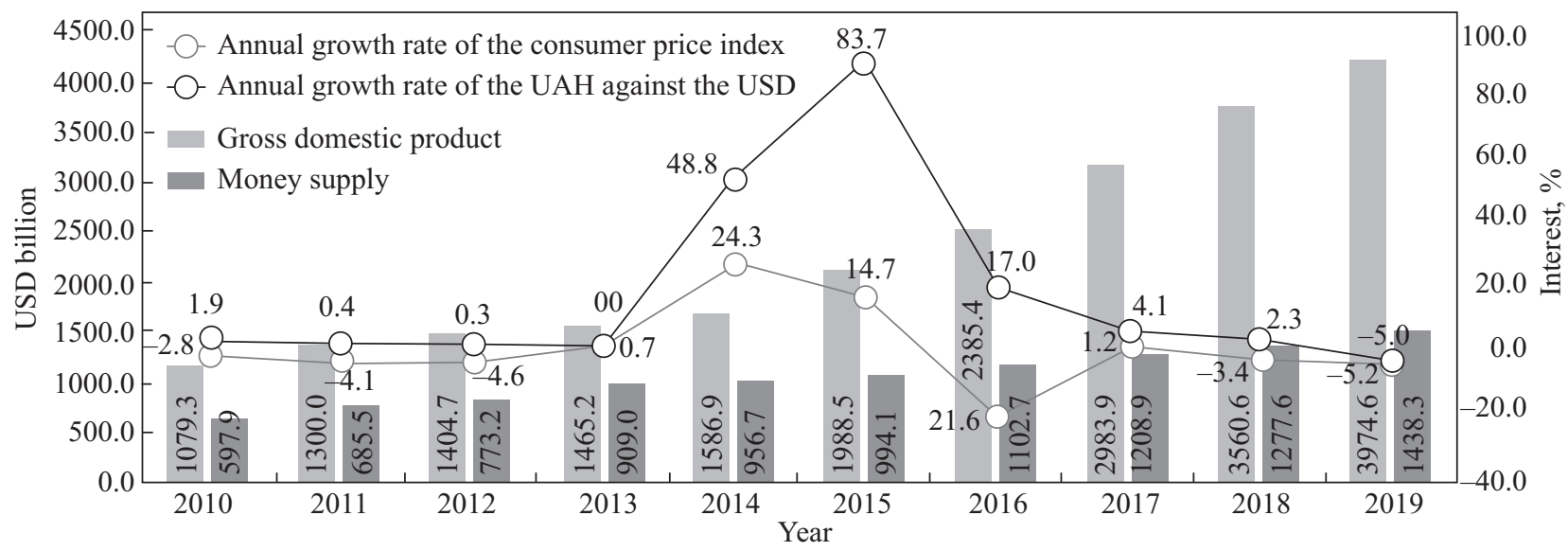

Fig. 6. Dynamics of gross domestic product, money supply, annual growth rates of the consumer price index and the UAH exchange rate against the USD, 2010 - 2019, UAH billion, \%

Source: estimated by the authors based on data [13].

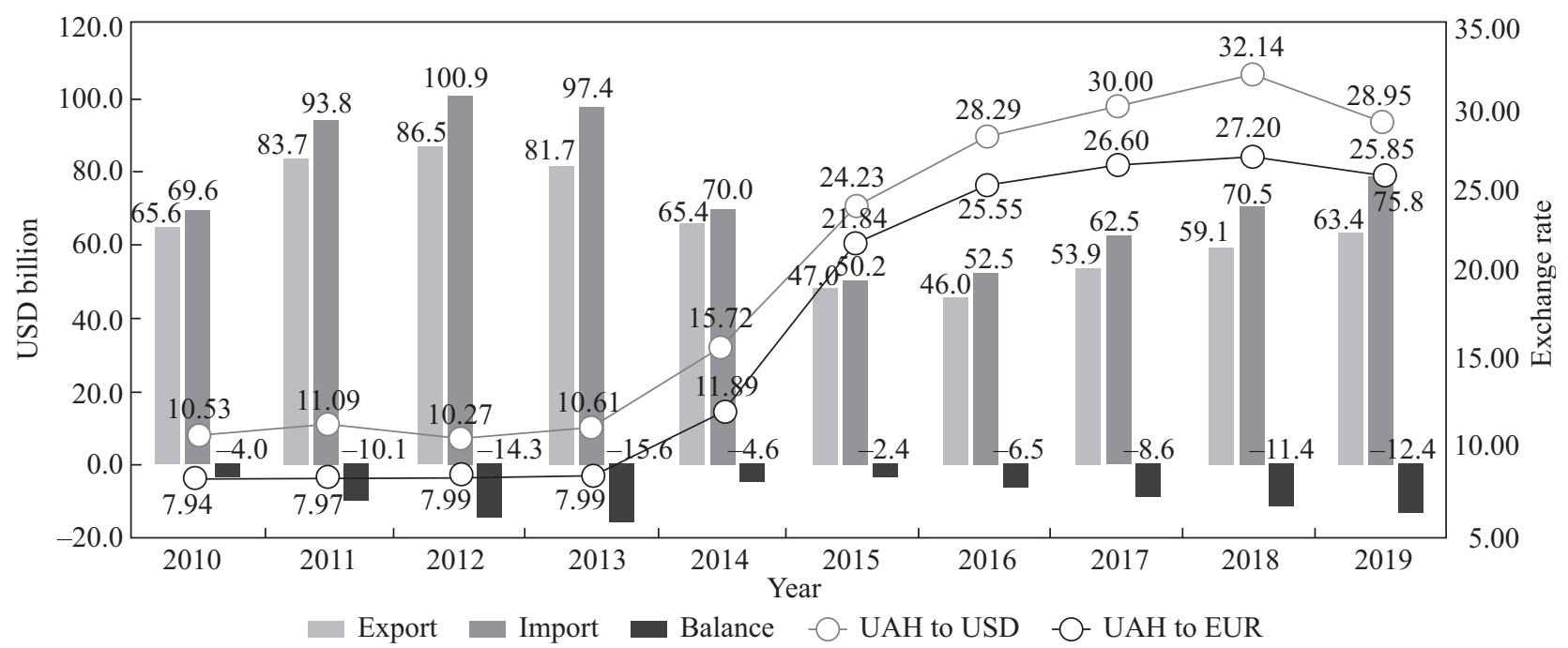

Fig. 7. Dynamics of export-import operations and UAH exchange rate against foreign currencies, 2010-2019, USD billion Source: calculated by the authors based on data [13].

state's interests that the citizens of Ukraine keep their money savings in Ukrainian banks without fear of losing them.

Developing a monetary policy that is adequate to global trends is especially important for Ukraine. The difficult economic situation in Ukraine in the early 1990s, the currency and financial crisis of 1998, the financial and economic crisis of 20082009 , as well as the fall of the national economy in 2014-2015, exacerbating the problem of financial security, determined the importance of set- ting goals, choosing methods and tools for implementing the monetary policy of the state.

Currency regulation of the domestic currency rates is aimed at its devaluation to protect the domestic market and overcome the BOP deficit (Fig. 6).

In order to improve the level of financial security of Ukraine, it became necessary to revise the exchange rate policy.

A significant underestimation of the domestic currency and large-scale devaluations of the past 


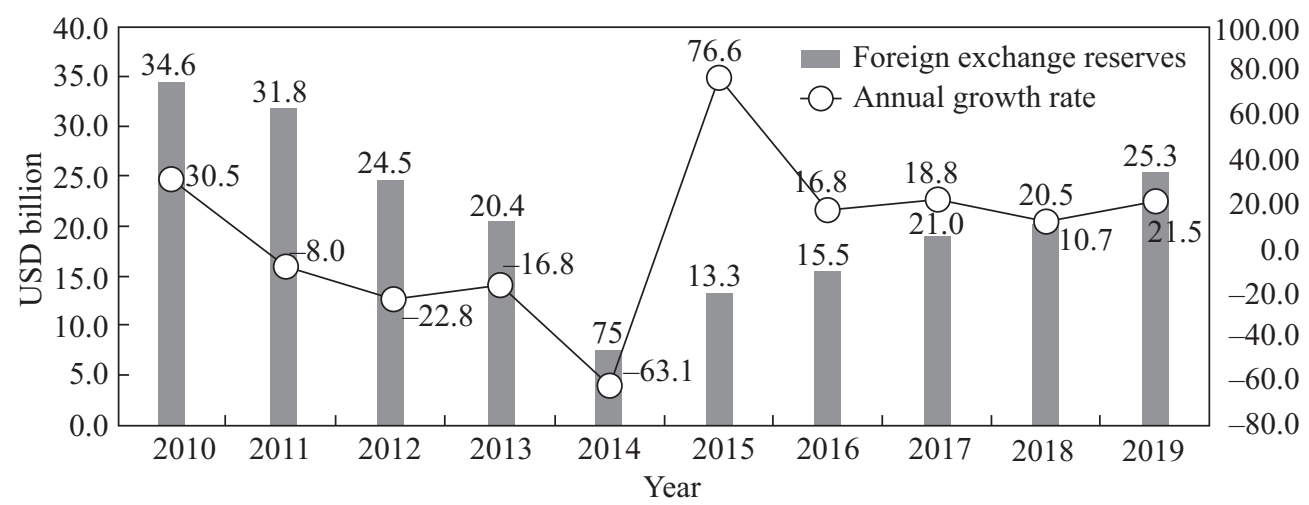

Fig. 8. Dynamics of foreign exchange reserves of the National Bank of Ukraine, 2010-2019, USD billion

Source: calculated by the authors based on data [13].

years created unfavorable conditions for Ukrainian exporters. This ensured the reduction of the foreign trade balance with a deficit, an outflow of foreign exchange and, accordingly, a decrease in foreign exchange reserves from USD 34.6 billion, in 2010, to USD 25.3 billion, in 2019. The indicators of export-import operations, calculated according to the methodology of the National Bank of Ukraine, indicate the annual predominance of imports over exports (in 2019, USD 12.4 billion), which, in turn, causes the formation of a negative trade balance (Fig. 7).

An important indicator of the state's financial security is the stability and convertibility of the national currency. This can be achieved in the presence of perfect foreign exchange legislation, sufficient reserves of the National Bank, effective foreign exchange policy in the state. The stability of the national currency, its support has their own special forms and methods of identification and functioning. Thus, the sources of foreign currency inflow to the state and the directions of its use, the possibility of free access to the purchase of foreign currency on the market, the pursuit of a policy of exchange rate formation by establishing a "floating" exchange rate regime, etc., are becoming important [7, 291].

Despite the negative balance of export-import operations in the conditions of favorable conditions on foreign markets, the balance of foreign exchange interventions of the National Bank of
Ukraine at the end of 2019 turned out to be positive (USD 7.9 billion), which contributed to an increase in the gross international reserves of the state, the growth rate of which was $21.5 \%$, and ensured the strengthening of the position of the national currency. The country's foreign exchange reserves as of 2019 amounted to USD 25.3 billion (Fig. 8).

No less important for the financial security of Ukraine is countering the dollarization of the state's monetary sphere, which exists outside of banks, which is a condition for the functioning and development of the shadow economy. Moreover, attention is drawn to the fact that it is consistently high. This indicates the distrust of individuals and legal entities in the state's banking system and the uncertainty of currency owners in the stability of the financial system of Ukraine in the future [6, 149].

During 2016-2019, the dynamics of dollarization of money supply, deposits, and loans gradually decreased simultaneously, but this did not indicate an improvement in the general situation, because the level of dollarization of the national economy of Ukraine was still at a high level (Fig. 9).

The strategy for ensuring financial security should determine the prospects for ensuring the stability of the financial, monetary and banking systems, and the development of the national economy. That is why one of the most important directions in implementing the financial strategy in the 


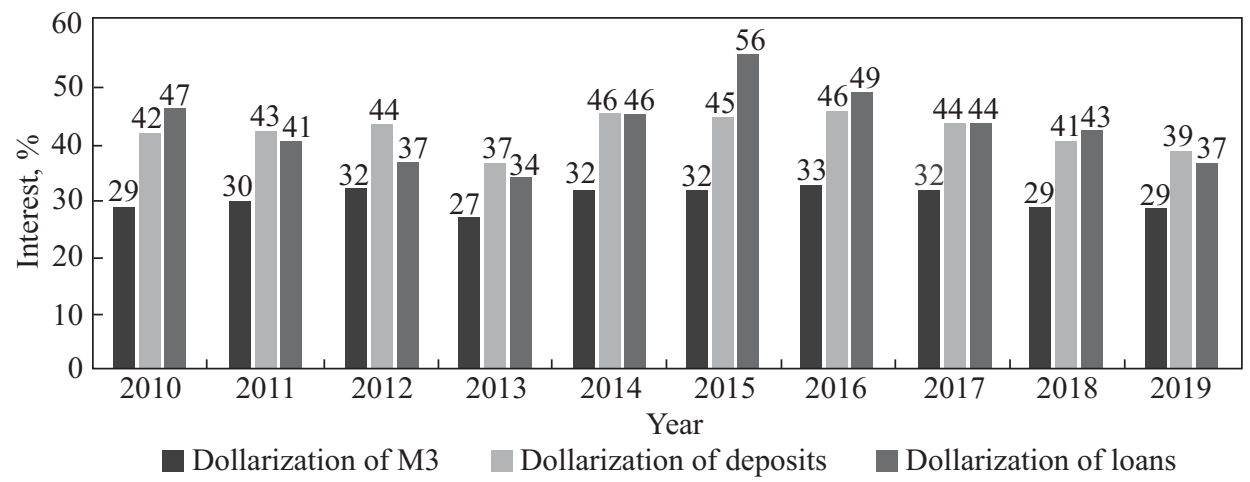

Fig. 9. Dynamics of dollarization of the national economy of Ukraine, 2010-2019, \% Source: estimated by the authors based on data [13].

field of exchange rate policy of Ukraine is the opposition to the dollarization of the state's monetary sphere.

The massive withdrawal of capital from Ukraine abroad reached a threatening scale, which also indirectly testifies to the mistrust of its owners in the banking system of the state. At the same time, the source of such capital is mainly the redistribution of state property, non-return of proceeds for exported products, tax evasion, and speculative financial transactions. Therefore, on the one hand, it is necessary to strengthen the responsibility for concealing income abroad, and on the other, to create legislative conditions for the legalization of non-criminal capital exported from the country in Ukraine [6, 149].

To ensure the financial security of Ukraine, the following comprehensive measures are advisable: development of a financial security strategy, formation and implementation of state and local budgets, monitoring of indicators for assessing financial security, monetary and financial stabilization, a strategy for the development of the banking system, control of the banking system, strengthening payment discipline, tax regulation, control over the withdrawal of capital from Ukraine abroad, ensuring the functioning of the securities market and the stock market, currency regulation, liberalization of capital movement.

Financial security of Ukraine is possible only if the financial, monetary and banking systems are balanced and resistant to external and internal fac- tors. However, today the financial security of Ukraine is under threat. After all, all the components of financial security are in an unsatisfactory state. The banking system of Ukraine belongs to foreigners (32\% of banks with $100 \%$ foreign capital), there is a process of ousting the national currency by foreign one (dollarization level is $29 \%$ ) and there is a constant imbalance in the state budget (the state budget deficit is UAH 78.05 billion). All this poses a threat to the financial security of Ukraine.

The steady trend towards a decrease in longterm lending (19.6\% in the loan portfolio of Ukrainian banks) is extremely negative. Its reduction is facilitated by the consistently high discount rate of the National Bank of Ukraine (13.5\%), the inflation rate $(4.1 \%)$, and a decrease in the resource base of banks. At one time, the implementation of monetary reform was not used for the organic combination of monetary and financial stabilization. The sale of foreign currency to individuals has an inappropriate character, a large amount of currency is in the hands of the population. Citizens of Ukraine do not have confidence in the domestic banking system.

The implementation of financial, currency, credit measures, the adoption of changes in the legislative framework, and the development of a financial security strategy for Ukraine are becoming increasingly important, given the problems that exacerbate the financial security of Ukraine. The implementation of these measures will contribute to strengthening the financial security of Ukraine. 


\section{REFERENCES}

1. Boy, N. (2017). Finance-security: Where to go? Finance and Society, 3(2), 208-215. https://doi.org/10.2218/finsoc. v3i2.2580.

2. Vasylieva, T., Jurgilewicz, O., Poliakh, S., Tvaronavičienė, M., Hydzik, P. (2020). Problems of measuring country's financial security. Journal of International Studies, 13(2), 329-346. https://doi.org/10.14254/2071-8330.2020/13-2/22.

3. Vasylchyshyn, O. B. (2016). The ways of increasing the level of financial security of Ukrainian banking system in the conditions of political and economic imbalances. Black sea economic studies, 7, 221-225 [in Ukrainian].

4. De Goede, M. (2017). Financial security. Finance and Society, 3(2), 159-172. https://doi.org/10.2218/finsoc. v3i2.2575.

5. Ivanova, O. B., Romanova, T. F., Kostoglodova, E. D., Romanov, D. G. (2017). Strategic directions of the country's ensuring financial security. European Research Studies Journal, XX(3B), 461-468. https://doi.org/10.35808/ersj/801.

6. Kalantai, A. M. (2012). Place and role of financial security its national interests. Collection of scientific works of the National University of State Tax Service of Ukraine, 1, 143-153 [in Ukrainian].

7. Nechiporuk, L. V. (2012). Strengthening of a threat to the financial security of the state in conditions of financial globalization. Collection of scientific works of the National University of State Tax Service of Ukraine, 1, 281-298 [in Ukrainian].

8. Radionov, Yu. D. (2015). Financial security Ukraine: problems and ways to ensure. Economy and State, 11, 55-59 [in Ukrainian].

9. Reznik, O., Getmanets, O., Kovalchuk, A., Nastyuk, V., Andriichenko, N. (2020). Financial security of the state. Journal of Security E S Sustainability Issues, 9(3), 843-852. https://doi.org/10.9770/jssi.2020.9.3(10).

10. Smokvina, A. A. (2014). Financial security as strategic component of economic security of Ukraine. Economics: time realities, 3(13), 30-36 [in Ukrainian].

11. Tarangul, L. L. (2017). Financial security of Ukraine and the instruments of its assuring. Economic Herald. Series: Finance, Accounting, Taxation, 1, 201-208. https://doi.org/10.33244/2617-5932.1.2017.201-208 [in Ukrainian].

12. Yurii, S. I., Fedosov, V. M. (Eds.). (2012). Finances. Kyiv: Znannia [in Ukrainian].

13. National Bank of Ukraine. (2020, August 21). National Bank of Ukraine. URL: https://bank.gov.ua/en (Last accessed: 12.12.2020).

14. Sheludko, N. M. (2008). The credit mechanism of realization of investment policy. Extended abstract of candidate's thesis. Kyiv [in Ukrainian].

15. Sytnyk, N. S., Vaskiv, I. M. (2018). Financial security of banks as one of the state financial safety. Scientific notes of Taurida National V. I. Vernadsky University Series: Economy and Management, 29(68), 6, 129-132 [in Ukrainian].

Received 23.12.2020

Revised 17.04.2021

Accepted 06.05.2021

О.В. Калініченко (https://orcid.org/0000-0003-2688-859X),

B.С. Лесюк (https://orcid.org/0000-0002-8370-6513)

Полтавський державний аграрний університет,

вул. Сковороди, 1/3, Полтава, 36003, Україна,

+380 53250 0273, pdaa@pdaa.edu.ua

\section{ОЦІНКА РІВНЯ ФІНАНСОВОЇ БЕЗПЕКИ УКРАЇНИ}

Вступ. В умовах розвитку глобалізаційних процесів та інтеграції національної економіки у світовий фінансовий простір все більшого значення набуває проблема формування фінансової безпеки України. Вона зачіпає та зв’язує воєдино всі галузі національної економіки, суб’єктів господарювання, суспільство, політику, економіку, фінанси тощо.

Проблематика. На сучасному етапі економічного розвитку України одним із першочергових завдань державної політики є гарантування фінансової безпеки держави, адже, забезпечення її спрямовано на подолання економічної кризи та підвищення добробуту громадян України.

Мета. Проведення оцінки фінансової, грошово-кредитної та банківської системи України, а також розробка практично значимих пропозицій щодо забезпечення фінансової безпеки України.

Матеріали й методи. Аналітичним матеріалом слугували дані Національного банку України, для обробки яких застосовано економіко-математичні методи, статистичний та індикативний аналізи. 
Результати. Визначено, що розбалансованість державного бюджету є головним дестабілізуючим чинником кризи державних фінансів. Досліджено динаміку кількості банків в Україні: не зважаючи на зменшення кількості банків 3 іноземним капіталом, ї частка за останні роки значно збільшилася, що перешкоджає ефективному розвитку банківської системи України. Істотне недоцінювання вітчизняної валюти та масштабні девальвації попередніх років створили несприятливі умови для українських експортерів, що забезпечило зведення зовнішньоторговельного балансу з дефіцитом, відплив іноземної валюти й, відповідно, зменшення золотовалютних резервів.

Висновки. Стратегія формування фінансової безпеки повинна визначати перспективу забезпечення стійкості фінансової, грошово-кредитної та банківської системи, розвитку національної економіки. Зважаючи на проблеми, що загострюють фінансову безпеку України, все більшого значення набуває здійснення фінансових, валютних, кредитних заходів, прийняття змін до законодавчої бази, розробка стратегії фінансової безпеки України.

Ключові слова: фінансова безпека, грошово-кредитна система, банківська система, бюджет, зовнішній борг, банки, національна економіка. 